\title{
Use of non-steroidal anti-inflammatory drugs in early pregnancy and preterm birth: Is the jury still out?
}

\author{
Lara Lemon ${ }^{1}$ \\ ${ }^{1}$ University of Pittsburgh Medical Center
}

March 31, 2021

\section{Hosted file}

BJOG_Invitied_MiniCommentary_NSAIDsandPTB_Lemon_3.3.2021.pdf available at https://authorea. com/users/405075/articles/516108-use-of-non-steroidal-anti-inflammatory-drugs-in-earlypregnancy-and-preterm-birth-is-the-jury-still-out 